\title{
Long Non-Coding RNA FENDRR: Gene Structure, Expression, and Biological Relevance
}

\author{
Przemyslaw Szafranski * (10) and Paweł Stankiewicz \\ Department of Molecular and Human Genetics, Baylor College of Medicine, Houston, TX 77030, USA; \\ pawels@bcm.edu \\ * Correspondence: pszafran@bcm.edu
}

check for updates

Citation: Szafranski, P.; Stankiewicz, P. Long Non-Coding RNA FENDRR: Gene Structure, Expression, and Biological Relevance. Genes 2021, 12, 177. https://doi.org/10.3390/genes 12020177

Academic Editor: Anton Petrov

Received: 24 December 2020

Accepted: 21 January 2021

Published: 27 January 2021

Publisher's Note: MDPI stays neutral with regard to jurisdictional claims in published maps and institutional affiliations.

Copyright: (c) 2021 by the authors. Licensee MDPI, Basel, Switzerland. This article is an open access article distributed under the terms and conditions of the Creative Commons Attribution (CC BY) license (https:// creativecommons.org/licenses/by/ $4.0 /)$.

\begin{abstract}
The FOXF1 Adjacent Noncoding Developmental Regulatory RNA (Fendrr) plays an important role in the control of gene expression in mammals. It is transcribed in the opposite direction to the neighboring Foxf1 gene with which it shares a region containing promoters. In humans, FENDRR is located on chromosome 16q24.1, and is positively regulated both by the FOXF1 distant lung-specific cis-acting enhancer and by trans-acting FOXF1. Fendrr has been shown to function as a competing endogenous RNA, sponging microRNAs and protein factors that control stability of mRNAs, and as an epigenetic modifier of chromatin structure around gene promoters and other regulatory sites, targeting them with histone methyltrasferase complexes. In mice, Fendrr is essential for development of the heart, lungs, and gastrointestinal system; its homozygous loss causes embryonic or perinatal lethality. Importantly, deregulation of FENDRR expression has been causatively linked also to tumorigenesis, resistance to chemotherapy, fibrosis, and inflammatory diseases. Here, we review the current knowledge on the FENDRR structure, expression, and involvement in development and tissue maintenance.
\end{abstract}

Keywords: regulatory RNA; ceRNA; divergent genes; lncRNA enhancer; lung development; fibrosis; drug resistance

\section{Introduction}

Nearly the entire human genome is transcribed; however, only approximately $2 \%$ of the transcriptome becomes translated into polypeptides longer than 100 amino acids $[1,2]$. Long non-coding RNAs (lncRNAs) are classified as transcripts of more than $200 \mathrm{nt}$ in length, showing a very limited translational potential. Like mRNAs, most lncRNAs are synthesized by RNA polymerase II and can be capped, polyadenylated, or spliced. LncRNAs have been found in the nucleus and/or cytoplasm. They can functionally interact with microRNAs (miRs), mRNAs, dsDNA, or proteins [3,4].

A subset of anti-sense lncRNAs have their $5^{\prime}$ ends located in proximity to the $5^{\prime}$ ends of the protein-coding genes transcribed in the opposite direction. In some cases, those divergent genes may overlap (e.g., RNF157-AS1 and FOXJ1, FOXC2-AS1 and FOXC2, ZCCHC14-DT and ZCCHC14). In other cases, like lncRNA gene FENDRR (FOXF1 Adjacent Noncoding Developmental Regulatory RNA; HGNC: 43894, MIM: 614975) and the transcription factor (TF)-coding FOXF1, they share a genomic region containing promoters. The symbol FENDRR is an acronym for the Fetal-lethal Non-coding Developmental Regulatory RNA and reflects the significance of this lncRNA in early embryonic development [5]. Previously, FENDRR was referred to as FOXF1-AS1, lincFOXF1, onco-lncRNA-21, or TCONS_00024240. FENDRR was identified in the studies that expanded the catalog of human lncRNAs to over 3000 based on their (i) distinctive histone 3 (H3)-based chromatin signature (H3K4me3-H3K36me3) that marks transcribed genes and (ii) limited protein coding potential [6]. 
Here, we review the current knowledge on this important but still relatively poorly understood regulatory lncRNA, including the most recent studies on the control of its expression and potential targets in the developing lungs.

\section{FENDRR Structure}

In humans, FENDRR maps to chromosome 16q24.1 at chr16:86,474,529-86,509,099 (GRCh38; ENSG00000268388, RNAcentral: http://rnacentral.org, [7]) (Figure 1A). However, due to a variety of FENDRR transcription start sites (TSS) and alternative splicing, the combined genomic region coding for all FENDRR transcripts is actually larger, $\sim 37 \mathrm{~kb}$ in size, mapping between chr16:86,473,637 for the $3^{\prime}$ end of the FENDRR:25 transcript and chr16:86,510,615 for the $5^{\prime}$ end of the HSALNT0234884 transcript (LncBook: http: //bigd.big.ac.cn/lncbook, [8]) (Figure 1A,B). Due to the presence of two to six (10 in the NONHSAT174160.1 isoform) relatively short exons, FENDRR isoforms are only $\sim 0.4-4 \mathrm{~kb}$ in size after splicing. LncBook, a curated database of human lncRNAs, incorporated in a non-coding RNA database RNAcentral, lists 50 FENDRR transcripts (examples are shown in Figure 1A,B). Fourteen of them are annotated in the GENCODE database (http: / / www.gencodegenes.org, [9]) as FENDRR-201 to 214 (Figure 1A). The diversity of FENDRR splicing contrasts with that of the neighboring protein-coding FOXF1 gene that features only a single isoform in humans, and supports a contention [10] that non-coding genes undergo alternative splicing more often than the protein-coding genes.

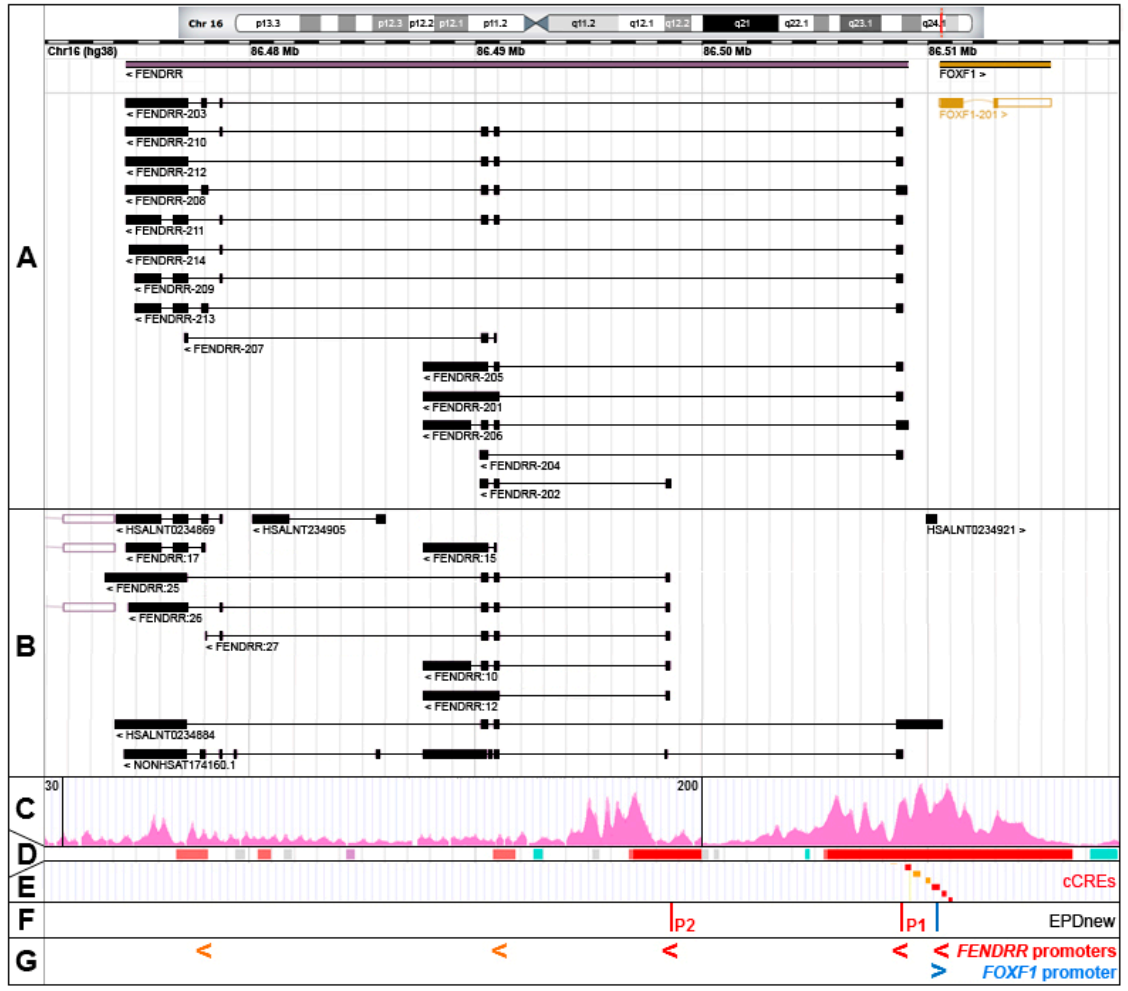

Figure 1. The FOXF1 Adjacent Noncoding Developmental Regulatory RNA (FENDRR) gene, alternatively spliced FENDRR transcripts, and promoters. (A) GENCODE annotated FENDRR isoforms (RNAcentral browser screenshot). (B) Selected additional FENDRR isoforms listed in RNAcentral. (C) Chromatin histone 3 modification, H3K4me3, usually found around active promoters (ENCODE ChIP-seq data from human lung fibroblasts, HLFs). (D) Ensembl-annotated promoters (red) and promoter flanking regions (orange). (E) ENCODE candidate cis-regulatory elements (cCREs, promoters are in red). (F) Eukaryotic promoter database (EPDnew)-annotated promoters. (G) Compilation of FENDRR promoters: EPDnew-annotated, cCRE promoters (red) and CCRE promoter flanking regions (orange). Note that promoter locations correlate with $5^{\prime}$ ends of the majority of FENDRR isoforms. 
FENDRR has been predicted to have a very low coding capability based on PRIDE reprocessing $2.0(=0)$, PhyloCSF score $(=65.5245)$, CPAT coding probability $(=28.39 \%)$, and Ribosome-profiling: Lee translation initiation sites $(=0)$ and Bazzini small ORFs $(=0)$ predictions (LNCipedia: http://lncipedia.org). In contrast to evolutionary conservation of FOXF1, the orthologs of human FENDRR are best conserved among higher primates and have not been identified in animals other than mammals (http:/ / genome.ucsc.edu/ ENCODE).

\section{FENDRR Transcription}

\subsection{Promoter}

The chromatin hallmarks of a human promoter include (i) a nucleosome-free region around and upstream of a transcription start site (TSS), (ii) a peak of RNA polymerase II binding slightly downstream of TSS and usually overlapping with the TF binding sites, and (iii) several H3K4me3-marked nucleosomes especially in the downstream portion of the promoter region [11]. Taking into account these criteria, FENDRR transcription can start from at least three promoters. The majority of the FENDRR isoforms are transcribed from the intergenic promoter P1, annotated in the Eukaryotic promoter database (EPDnew, http: / / epd.vital-it.ch, [11]) as a promoter element mapping at chr16:86,508,876-86,508,935 and in ENCODE as candidate cis-regulatory element (cCRE) mapping at chr16:86,508,968-86,509,250 (Figure 1C-F). This promoter is located within a large island of $365 \mathrm{CpGs}$ and is sensitive to DNA methylation. It belongs to a class of promoters with a dispersed TSS pattern. The emerging view on the functioning of human promoters is that they are intrinsically bi-directional and their actual directionality is controlled both at the transcriptional and/or post-transcriptional levels [12-16]. In support of this notion, an abortive transcription (the HSALNT0234921 transcript mapping to chr16:86,510,010-86,510,341) originates possibly from this promoter in the direction opposite to the FENDRR transcription (Figure 1B). The FENDRR promoter with the apparently second highest usage, P2 (EPDnew-annotated element: chr16:86,498,542-86,498,601), is located within FENDRR intron 1 and may initiate FENDRR-202, FENDRR:10 to 12, 26, 27, and 29 transcripts (Figure 1). As in the case of the intergenic promoter, the intragenic FENDRR promoter P2 is located within an island of 184 CpGs. It is possible that FENDRR-207, and FENDRR:14 to 17 transcripts initiate from two other intragenic promoters located further downstream (Figure 1). Interestingly, one of the FENDRR isoforms, the HSALNT0234884 transcript (chr16:86,474,121-86,510,614), begins with a cCRE (chr16:86,510,620-86,510,824) overlapping the $5^{\prime}$ end of the non-coding portion of the FOXF1 exon 1 (Figure 1).

\subsection{Enhancer}

The lung-specific FOXF1 enhancer is located $270 \mathrm{~kb}$ upstream to the FOXF1 gene [17-21]. This enhancer was originally described as $\sim 60 \mathrm{~kb}$-large regulatory region based on the overlap of heterozygous copy number variant $(\mathrm{CNV})$ deletions detected in patients with Alveolar Capillary Dysplasia with Misalignment of Pulmonary Veins (ACDMPV, MIM: 265380) due to FOXF1 haploinsufficiency [17]. It consists of six regulatory elements annotated as enhancers in GeneHancer database [22], each overlapping several cCREs (Figure 2A). In cultured human lung fibroblasts (HLFs) these regulatory elements feature H3K27ac and $\mathrm{H} 3 \mathrm{~K} 4 \mathrm{me} 1$ chromatin modifications which are the predominant $\mathrm{H} 3$ marks at the nucleosomes flanking the active/poised enhancer elements (ENCODE). Moreover, chromosome circular conformation capture (4C) analysis in human pulmonary microvascular endothelial cells [17] and 3C analysis in cells isolated from mouse embryonic lungs [19] showed that this distant enhancer physically interacts with the FENDRR-FOXF1 intergenic promoter region. Interestingly, we have found a $\sim 35 \mathrm{~kb}$-large genomic instability hotspot, featuring the evolutionarily young LINE1 elements, L1PA2 and L1PA3 flanking five Alu repeats, located at the distal edge of this enhancer region, and responsible for several pathogenic enhancer deletions of which the distal breakpoints are mapped within the 
hotspot [23]. The appearance of this genomic instability hotspot in the course of evolution correlates with the branching out of the Homo-Pan-Gorilla clade.

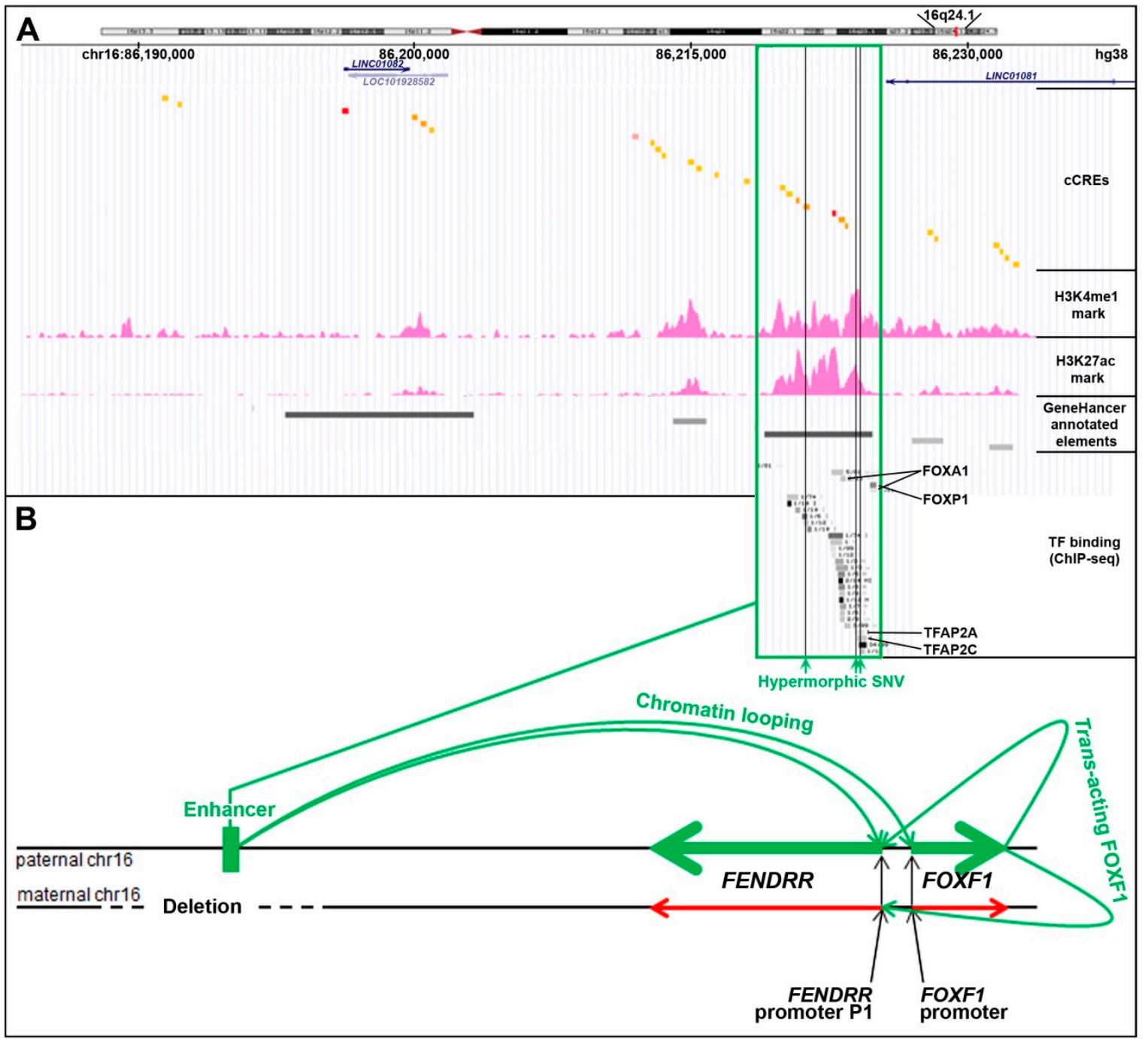

Figure 2. Cis- and trans-regulation of the FENDRR expression in the lungs (modified from [24]). (A) FENDRR-FOXF1 distant enhancer region, located $\sim 250 \mathrm{~kb}$ centromerically to the $3^{\prime}$ end of FENDRR (UCSC genome browser screenshot). The most essential part of this enhancer is shown in green frame. The enhancer features histone 3 modifications, usually found in active enhancers, and ChIP-seq-determined in HLFs binding sites for numerous transcription factors (TF): FOXA1, FOXP1, CEBPB, MAFK, RAD21, SMARCC1, CTCF, GTF2F1, KAP1, TBP, JUNs, EP300, STAT3, FOS, TFAP2A, and TFAP2C (ENCODE). Single nucleotide variants (SNVs, vertical green lines) that map to the essential part of the enhancer have been proposed to increase activity of the undeleted allele of the enhancer and mitigate ACDMPV phenotype in patients with heterozygous $\mathrm{CNV}$ deletions of the enhancer. (B) Scheme of mono-allelic expression of FENDRR from the paternally inherited chromosome 16 in the presence of a heterozygous CNV deletion of the maternal allele of the FENDRR-FOXF1 enhancer. The drawing shown is not to scale.

Based on the overlap of additional pathogenic CNV deletions causative for ACDMPV and the presence of hypermorphic single nucleotide variants (SNVs) in the undeleted allele of the enhancer that significantly ameliorated the lethal ACDMPV phenotype by increasing FOXF1 expression, this enhancer was narrowed to the $\sim 10$ kb-large most essential region $[20,21]$. This narrowed interval harbors a GeneHancer-annotated regulatory element GH16J086219 (chr16:86,218,986-86,224,837, overlapping with seven cCREs) that corresponds to one of the super-enhancers proposed by Hnisz et al. [25] based on their 
analysis of the H3K27ac ChIP-seq data from a spectrum of human cell types including fetal lung fibroblasts IMR-90.

Recently, through a correlation of the parental origins of chromosome 16, bearing the heterozygous CNV deletions of this enhancer with that of the transcribed FENDRR allele, we have found that the FOXF1 enhancer regulates in cis also FENDRR [24] (Figure 2B). This finding may help explain the results of in-depth expression analyses of mouse Fendrr/Foxf1 and other lncRNA/protein-coding divergent gene pairs showing that lncRNAs mimic the expression patterns of their protein-coding neighbors [26,27].

Besides the FENDRR/FOXF1 distant enhancer, there are several other regions upstream or downstream to TSS of FENDRR (within a large GeneHancer-annotated element GH16J086491) that, based on their H3 chromatin signature and eQTLs (expression quantitative trait loci), may potentially function as FENDRR proximal enhancers or modulators of its tissue specificity. For instance, in mice, a genomic region located $\sim 1 \mathrm{~kb}$ downstream of Foxf1 functions as Foxf1 enhancer in foregut mesoderm and mesenchyme of developing liver and lungs [28]. It was also shown by 3C, using mouse lung cells, that this regulatory element physically interacts in vivo with Fendrr-Foxf1 intergenic region [19].

\subsection{Regulation of FENDRR by FOXF1}

In contrast to the co-regulation of FENDRR and FOXF1 expression by the same cisacting distant enhancer, the involvement in this regulation of the trans-acting TF FOXF1 was unexpected. Depletion of FOXF1 in lung fibroblasts by siRNA or FOXF1 point mutations causative for ACDMPV were found to correlate with a substantial $(\sim 50 \%)$ decrease in FENDRR levels (measured by qPCR with TaqMan assay for the exon $1 / 2$ junction, and RNAseq, respectively) [24]. Foxf1 was also shown to likely support Fendrr expression in mice [29]. However, the binding of FOXF1 to the FENDRR promoters or the enhancer has yet to be documented. Interestingly, FENDRR promoters and the enhancer all contain several variants of the FOX TF binding RYAAAYA motif ( $\mathrm{R}=$ purine, $\mathrm{Y}=$ pyrimidine; [30]), suggesting a possibility of direct regulation of FENDRR expression by FOXF1. In support of this notion, ChIP-seq experiments of the TF binding (ENCODE) showed that other members of the FOX TF family, especially FOXA1, bind to the FENDRR major promoter, P1, and the essential region of the enhancer. In addition, FOXF1 might also indirectly regulate FENDRR expression through the control of factors that directly regulate FENDRR. Based on our RNA-seq analyses of the ACDMPV transcriptomes, of about 40 TFs potentially interacting, based on ENCODE's ChIP-seq data, with the FENDRR primary P1 promoter and the most essential portion of the enhancer, the expression of a histone methyltransferase subunit, ASH2L (binding next to FENDRR P1 promoter's cCRE), positively correlates with the expression of FOXF1 (reduced by $~ 40 \%$ in ACDMPV cases linked to FOXF1 deficiency) [24]. ASH2L can interact with MLL [31], a Trithorax-group (TrxG) protein involved in histone 3 methylation, H3K4me3, which is usually associated with open chromatin at active promoters. Thus, ASH2L might mediate positive regulation of FENDRR expression by FOXF1.

\subsection{Other Factors Controlling FENDRR Transcription}

Another potential regulator of FENDRR expression is a pro-apoptotic Annexin 2 (ANXA2) [32]. In electrophoretic mobility shift assay performed using extracts from rat pancreatic acinar cells and fragments of the Fendrr promoter, ANXA2 was specifically bound to the Fendrr intergenic promoter, and the increase in Anxa2 expression in caeruleintreated pancreatic cells positively correlated with the increase in the Fendrr level.

Using a reporter assay in lung cancer cells lines, FENDRR was also shown to be positively regulated by EGR2 and TFAP2A [33]. Both these TFs are known to bind to the FENDRR primary promoter based on ChIP-seq data from lung fibroblasts (ENCODE).

Interestingly, induced expression of Mesp1 during cardiomyocyte differentiation also led to upregulation of several genes including Fendrr [34]. Thus, Fendrr can be a down- 
stream effector of MESP1, a TF best known as a master regulator of cardiovascular system development.

Regarding suppressors of FENDRR, its expression is negatively regulated in the lungs by SMAD3 (but not SMAD2), which is a major signal transducer for cell-membrane Ser/Tyr kinase receptors of TGF- $\beta 1$ [35].

Of note, using ChIP-seq for TBX2 and TBX4 in IMR-90 fibroblasts, we have found a specific binding of (i) TBX4 at chr16:86,223,833-86,225,160, largely overlapping the GH16J086219 regulatory element in the essential region of the FENDRR-FOXF1 enhancer, (ii) TBX4 at chr16:86,508,364-86,508,853 next to the FENDRR primary promoter, and (iii) TBX2 at $86,507,893-86,509,510$, overlapping the FENDRR primary promoter [36]. The functional significance of these interactions is currently unknown, but they suggest the existence of a direct regulatory relationship between TBX4-FGF10 and SHH-FOXF1 signaling pathways during lung development.

Lastly, it has been suggested that FENDRR expression can be regulated through the epigenetic modification of its promoter (P1) that overlaps a large CpG island. The hypermethylation of this promoter has been shown to correlate with suppression of FENDRR expression in gastric cancer-associated fibroblasts [37]. Hypermethylation of the FENDRR promoter was also found in $36 \%$ of non-small cell lung cancers [38].

\section{Mechanisms of FENDRR Functioning}

\subsection{Competing Endogenous RNA (ceRNA)}

The well-known activity exhibited by lncRNAs is to function as a molecular sponge. FENDRR was shown to sequester, by sequence complementarity, at least ten different miRs, resulting in an increase in the expression of genes whose mRNAs were targeted for degradation by those miRs (Table 1). The majority of miR binding sites in FENDRR have been mapped to the middle of the gene, in the region corresponding to the exon 4 of FENDRR-206 (RefSeq transcript variant 2) (Table 1, Figure 1A).

Importantly, ceRNA function may be controlled by alternative splicing. For instance, FENDRR-203, 209, 213 and 214 do not have exons corresponding to the exons 3 and 4 of FENDRR-206 that bind several miRs (Table 1). Likewise, FENDRR-207 cannot bind $m i R-184$, whereas $m i R-126$ can be bound by the $5^{\prime}$ extension of the exon 1 present only in FENDRR-206 or 208. In mice, miR-106b binds to the largest exon 4 of MS-Fendrr-202, but likely not to the isoforms MS-Fendrr-201 or MS-Fendrr-203 in which the portion of exon 4 bearing $m i R-106 b$ binding site is spliced out.

Besides interacting with miRs, FENDRR can directly and specifically bind to $3^{\prime}$ untranslated regions (UTRs) of mRNAs. In particular, FENDRR was shown to compete with the $\mathrm{Hu} / \mathrm{ELAV}$-like protein 1 (HuR) for binding to the AU-rich elements in the $3^{\prime} \mathrm{UTR}$ of the multi-drug resistance gene MDR1 (ABCB1) mRNA [44]. This interaction prevents binding of HuR to the MDR1 mRNA $3^{\prime} U T R$, destabilizing MDR1 mRNA. As expected, the overexpression of FENDRR in drug-resistant myeloid leukemia cells specifically decreased expression of MDR1, likely due to a decrease in HuR-bound MDR1 $3^{\prime} \mathrm{UTR}$ s, and improved the responsiveness of those cells to adriamycin [49].

In its role as a molecular sponge, FENDRR can specifically interact also with proteins. It was shown that $F E N D R R$ sequesters HuR and this interaction has a stabilizing effect on FENDRR, but contributes to the decrease in MDR1 mRNA levels and restoration of drug sensitivity [49,57]. Of note, miR-184 competes with HuR for binding to FENDRR and marks FENDRR for degradation by RISC/Ago [49]. Another protein found to bind to FENDRR is Iron-responsive Element Binding Protein 1 (IRP1), discussed later in the context of lung fibrosis [35]. IRP1 binds to FENDRR-201 and 205 last exon in the position that corresponds to the intron 3/exon 4 junction of FENDRR-206 or an intron in other isoforms. 
Table 1. MicroRNA-FENDRR interactions affected in cancer, fibrosis and other diseases.

\begin{tabular}{|c|c|c|c|c|c|c|}
\hline \multicolumn{2}{|c|}{ MicroRNA Binding to FENDRR } & \multicolumn{2}{|r|}{ MicroRNA Target } & \multicolumn{2}{|c|}{ Disease Association } & \multirow[b]{2}{*}{ Reference } \\
\hline MicroRNA & $\begin{array}{l}\text { MicroRNA Binding Site } \\
\text { on FENDRR (hg38) }\end{array}$ & Gene & Function & Disorder & $\begin{array}{l}\text { FENDRR } \\
\text { Expression }\end{array}$ & \\
\hline $\operatorname{miR}-15 a-5 p$ & $\begin{array}{c}\text { Exon 4: } \\
86,488,730-86,488,724\end{array}$ & \multirow{2}{*}{ TUBA1A } & \multirow{2}{*}{$\begin{array}{l}\text { Suppresses cell proliferation } \\
\text { and viability }\end{array}$} & \multirow{2}{*}{ Cervical cancer } & \multirow{2}{*}{ Decreased } & \multirow{2}{*}{ [39] } \\
\hline$m i R-15 b-5 p$ & $\begin{array}{c}\text { Exon } 4: \\
86,488,743-86,488,723\end{array}$ & & & & & \\
\hline \multirow{4}{*}{$m i R-18 a-5 p$} & \multirow{4}{*}{$\begin{array}{c}\text { Exon } 4: \\
86,488,853-86,488,840\end{array}$} & IRF2 & $\begin{array}{l}\text { Pro-apoptotic, suppressor of } \\
\text { cell migration and proliferation }\end{array}$ & $\begin{array}{l}\text { Non-small cell lung } \\
\text { cancer }\end{array}$ & $\mathrm{n} / \mathrm{a}$ & {$[40]$} \\
\hline & & ING4 & Growth inhibitor & Colorectal cancer & Decreased & {$[41]$} \\
\hline & & RUNX1 & $\begin{array}{l}\text { Pro-apoptotic TF, suppressor of } \\
\text { cell proliferation, invasion and } \\
\text { migration }\end{array}$ & Prostate cancer & Decreased & [42] \\
\hline & & $\mathrm{NOTCH} 2$ & $\begin{array}{c}\text { Pro-Endothelial-Mesenchymal } \\
\text { Transition (EndMT), contributes } \\
\text { to cardiac fibrosis }\end{array}$ & $\begin{array}{l}\text { Hyperglycemia-induced } \\
\text { EndMT and cardiac } \\
\text { fibrosis }\end{array}$ & $\mathrm{n} / \mathrm{a}$ & {$[43]$} \\
\hline $\begin{array}{l}\text { miR-106b } \\
\text { (mouse) }\end{array}$ & Mouse Fendrr exon 5 & Smad3 & $\begin{array}{l}\text { Inhibits FOXF1 expression, } \\
\text { pro-fibrotic }\end{array}$ & $\begin{array}{l}\text { TAC-induced cardiac } \\
\text { fibrosis }\end{array}$ & Increased & {$[44]$} \\
\hline \multirow{4}{*}{ miR-126 } & \multirow{4}{*}{$\begin{array}{c}\text { Exon 1: } \\
86,509,005-86,508,980\end{array}$} & \multirow{2}{*}{ VEGFA } & Angiogenesis, apoptosis & $\begin{array}{l}\text { Hypertensive } \\
\text { intracerebral } \\
\text { hemorrhage }\end{array}$ & Increased & [45] \\
\hline & & & $\begin{array}{l}\text { Positively regulates multidrug } \\
\text { resistance gene } M R P 1\end{array}$ & $\begin{array}{l}\text { Non-small cell lung } \\
\text { cancer }\end{array}$ & $\mathrm{n} / \mathrm{a}$ & [46] \\
\hline & & EGFL7 & Tumor angiogenesis & $\begin{array}{c}\text { Hepatocellular } \\
\text { carcinoma }\end{array}$ & $\mathrm{n} / \mathrm{a}$ & [47] \\
\hline & & SOX2 & $\begin{array}{l}\text { Positively regulates expression } \\
\text { of } P L A C 1\end{array}$ & Gastric cancer & $\mathrm{n} / \mathrm{a}$ & [48] \\
\hline$m i R-184$ & $\begin{array}{c}\text { Exon 4: } \\
86,487,935-86,487,917\end{array}$ & $\begin{array}{l}M D R 1 \\
(A B C B 1)\end{array}$ & $\begin{array}{l}\text { Drug transporter (miR-184 } \\
\text { competes with HuR for } \\
\text { FENDRR; FENDRR + HuR - } \\
\text { MDR1; HuR > MDR1 }\end{array}$ & $\begin{array}{l}\text { Chronic myelogenous } \\
\text { leukemia; chemotherapy } \\
\text { resistance }\end{array}$ & Decreased & [49] \\
\hline \multirow{3}{*}{$m i R-214-3 p$} & \multirow{2}{*}{$\begin{array}{c}\text { Exon } 4: \\
86,488,737-86,488,725\end{array}$} & TET2 & $\begin{array}{l}\text { DNA demethylation (loss of } \\
\text { TET2 leads to hypermethylation } \\
\text { of tumor suppressor RASSF1A } \\
\text { promoter }\end{array}$ & \multirow{2}{*}{ Gastric cancer } & Decreased & {$[50]$} \\
\hline & & PTEN & $\begin{array}{l}\text { Tumor suppressor (negative } \\
\text { regulator of } \mathrm{Akt} / \mathrm{PKB} \\
\text { signaling) }\end{array}$ & & $\mathrm{n} / \mathrm{a}$ & [51] \\
\hline & $\begin{array}{c}\text { Six binding sites in exon } \\
4\end{array}$ & $\mathrm{n} / \mathrm{a}$ & $\mathrm{n} / \mathrm{a}$ & Lung fibrosis & Decreased & [35] \\
\hline $\operatorname{miR}-362-5 p$ & $\begin{array}{c}\text { Exon 4: } \\
86,487,984-86,487,963\end{array}$ & NPR3 & $\begin{array}{l}\text { Suppresses p38-MAPK } \\
\text { signaling }\end{array}$ & $\begin{array}{l}\text { Hepatocellular } \\
\text { carcinoma cells }\end{array}$ & Decreased & {$[52]$} \\
\hline$m i R-423-5 p$ & $\begin{array}{c}\text { Exon 3: } \\
86,490,399-86,490,388\end{array}$ & $G A D D 45 B$ & $\begin{array}{l}\text { Inhibits cell proliferation and } \\
\text { induces apoptosis }\end{array}$ & $\begin{array}{l}\text { Hepatocellular } \\
\text { carcinoma }\end{array}$ & Decreased & [53] \\
\hline$m i R-424$ & $\mathrm{n} / \mathrm{a}$ & FOXF1 & Suppressor of cell proliferation & Lung cancer & Decreased & [33] \\
\hline \multirow[b]{2}{*}{ miR-761 } & \multirow{2}{*}{$\begin{array}{c}\text { Exon 4: } \\
86,488,737-86,488725\end{array}$} & $\mathrm{n} / \mathrm{a}$ & $\begin{array}{l}\text { Suppressor of cell motility and } \\
\text { invasion }\end{array}$ & $\begin{array}{l}\text { Non-small cell lung } \\
\text { cancer }\end{array}$ & Decreased & [54] \\
\hline & & TIMP2 & $\begin{array}{c}\text { Inhibitor of matrix } \\
\text { metalloproteinases (MMPs) and } \\
\text { cell invasion }\end{array}$ & $\begin{array}{l}\text { Non-small cell lung } \\
\text { cancer }\end{array}$ & Decreased & [55] \\
\hline \multirow{4}{*}{$\begin{array}{l}\text { miR-148a } \\
\text { miR-195 } \\
\text { miR-196b } \\
\text { miR-301b }\end{array}$} & \multirow{4}{*}{$\mathrm{n} / \mathrm{a}$} & EPAS1 & \multirow{4}{*}{$\begin{array}{l}\text { FENDRR-miR-mRNA potential } \\
\text { associations deduced based on } \\
\text { comparative gene expression } \\
\text { analysis of TCGA-lung } \\
\text { adenocarcinoma datasets }\end{array}$} & \multirow{4}{*}{$\begin{array}{l}\text { Non-small cell lung } \\
\text { cancer }\end{array}$} & \multirow{4}{*}{ Decreased } & \multirow{4}{*}{ [56] } \\
\hline & & EDNRB & & & & \\
\hline & & $\mathrm{n} / \mathrm{a}$ & & & & \\
\hline & & SOX21 & & & & \\
\hline
\end{tabular}

\subsection{Scaffold and Guide}

LncRNAs function often as a platform on which certain RNA-binding proteins can be locally increased in abundance and multicomponent complexes assembled to target those ligands to specific genomic locations. FENDRR was found physically associated with the chromatin modifying histone methyltransferase complexes such as Polycomb Repressive 
Complex (PRC) 2 [5,6], TrxG/MLL complex [5,58], and with REST Corepressor (CoREST) 1 protein [6].

PRC2 primarily trimethylates H3 at Lys27 (H3K27me3), causing transcriptional silencing through chromatin compaction. Association of FENDRR with PRC2 was identified using RIP-ChIP assay in human fibroblasts (HLFs and human foot fibroblasts (HFFs)) with antibodies against two components of PRC2 complex, SUZ12 or EZH2 [6]. FENDRR was also found bound to EZH2 in lung cancer cells CALU1 [59]. Association of Fendrr with PRC2 was confirmed using a similar assay in extracts from embryonic mouse cells [5]. In addition, functional analyses in HLFs and HFFs demonstrated that siRNA-mediated depletion of FENDRR resulted in de-repression of the PRC2-regulated genes [6]. These results suggest that FENDRR not only can bind to chromatin-modifying complexes, but also can guide them to specific genomic locations such as promoters or enhancers. This hypothesis was verified in an in vitro mouse system by Grote et al. [5]. Using pool-down assay, they showed that Fendrr directs histone methyltransferase complexes to the Foxf1 and Pitx2 promoters, which independently showed a decrease in PRC2 occupancy with loss of Fendrr. A 20 nt-long Fendrr segment, mapping to mouse Fendrr exon 3 was predicted to form a triple-helix with complementary segments of the Foxf1 and Pitx2 promoters [5].

REST also represses transcription by forming a complex with CoREST1 and recruiting chromatin-modifying proteins, among others, to methylate $\mathrm{H} 3 \mathrm{~K} 9$ and demethylate H3K4me or H3K4me2, resulting in chromatin condensation [6]. CoREST proteins are best known for their role as part of the REST complex, but they can also repress target genes in the REST-independent manner [60]. Binding of CoREST1 to FENDRR was demonstrated in HLFs and HFFs using RIP-ChIP assay and antibodies against CoREST1 [6].

In contrast to the repressive PRC2 and CoREST complexes, TrxG/MLL proteins are responsible for transcription-activating methylation of $\mathrm{H} 3, \mathrm{H} 3 \mathrm{~K} 4 \mathrm{me} 3$. The physical interaction of TrxG/Mll complex with Fendrr was identified using a pool-down assay in the murine embryonic cell extracts with antibodies against a component of this transmethylase complex, WDR5 [5].

\section{FENDRR in Development and Disease}

\subsection{FENDRR Expression during Development}

Grote et al. [5] reported that Fendrr expression in mice is confined to the nascent lateral plate mesoderm. They found expression of Fendrr in cardiac mesoderm progenitor cells at the early midstreak stage E6.5-7. Sauvageau et al. [61] found that in mice developing respiratory and digestive tracts at E14.5, Fendrr is expressed in the pulmonary mesenchyme surrounding the bronchiolar epithelial cells, in mesenchymal cells of the developing mucosa, in the muscular layer of the gut, and in the lymphoid aggregations within mucosa of the gut. Lai et al. [62] showed that in E12.5 embryos, Fendrr is expressed in the frontonasal process, upper respiratory track, lungs, and the posterior aorta-gonad-mesonephron region.

Described by Grote et al. [5], homozygous loss of Fendrr was lethal at E13.75 due to heart and omphalocele defects. Sauvageau et al. [61] also showed that homozygous loss of Fendrr is lethal although at a later, perinatal stage; Fendrr ${ }^{-/-}$lungs at the pseudoglandular stage (E14.5) were hypoplastic, had decreased number of pulmonary arteries, and featured general failure of vasculogenesis. At E18.5, Fendrr ${ }^{-/-}$lungs had fewer and enlarged alveoli. The observed respiratory failure at birth was likely caused by the defects in lung maturation and vascularization. Regarding development of the esophagus and the gut, E18.5 embryos featured thinning of the mesenchymal layer of the mucosa and external smooth muscle layers in the esophagus. Moreover, they featured intraventricular septal heart defects prior to birth. Perinatal lethality in Fendrr ${ }^{-/-}$mice was also reported by Lai et al. [62]. E13.5 embryos had smaller lungs with globular and disorganized lobes. Mice died shortly after birth due to breathing problems. Some phenotypic differences between Fendrr knockout mice described by the three groups may be due to differences in the Fendrr ablation strategies used. While Grote et al. [5] eliminated Fendrr transcription by replacing the 1st exon of Fendrr with multiple transcription terminators, the other two 
groups $[61,62]$ replaced most of the Fendrr gene with the lacZ reporter while retaining the transcription from the endogenous Fendrr promoter.

In the adult mouse, Fendrr is highly expressed in the lungs and colon, then in the liver, spleen, brain, and testes (http://useast.ensembl.org/Mus_musculus) [61]. In humans, gene expression pattern determined using RNA-seq in 948 normal adults (the NIH Genotype-Tissue Expression (GTEx) project) showed the highest FENDRR levels in the bladder, lungs, esophagus, colon, prostate, and small intestine [63]. Similar results were independently obtained by other group using RNA-seq of transcriptomes from 27 different tissue samples from 95 normal adults [64]. These studies showed that FENDRR has the highest expression in the lungs, followed by urinary bladder, gall bladder, esophagus, prostate and appendix, and was almost undetectable in the heart, kidney, and liver.

\subsection{Alveolar Capillary Dysplasia with Misalignment of Pulmonary Veins (ACDMPV)}

The involvement of Fendrr in mouse lung development and the regulation of FENDRR expression by FOXF1 as well as by the FOXF1 enhancer suggest that FENDRR might be involved in etiology of ACDMPV and/or associated diseases. Point mutations involving FOXF1 and CNV deletions of FOXF1 or its enhancer are causative for ACDMPV in more than $80 \%$ of patients.

To determine whether any genes or pathways affected in ACDMPV lungs could be controlled by FOXF1 through FENDRR, we have performed RNA-seq in FENDRR-depleted (by siRNA or CRISPR/Cas9) IMR-90 cells [65]. Our preliminary ConsensusPathDBbased analyses of genes whose expression changed following FENDRR depletion in IMR90 cells suggest deregulation of some pathways also affected in the ACDMPV lungs, including those involved in RNA processing, cell cycle regulation, membrane trafficking, VEGFA-VEGFR2 signaling, TGF- $\beta$ signaling, EGF signaling, $\beta$-catenin-independent WNT signaling, $G$ protein signaling, and other processes [65]. Genes involved in vascular development, similarly affected in ACDMPV and FENDRR-depleted fibroblasts, include, e.g., PDGFRA, PLXNC1, or serotonin transporter genes SLC5A1 and SLC6A4 with roles in vascular remodeling [65]. Genes that were found upregulated in ACDMPV and FENDRR-deficient fibroblasts include, e.g., COL6A2 and ELN which might contribute to pulmonary arterial hypertension [65].

\subsection{Cancer}

Long non-coding RNAs have been shown to be involved in the pathogenesis of various malignant cancers as tumor suppressors or oncogenes [66-68]. FENDRR was proposed to have a tumor suppressor role by inhibiting cell proliferation, motility, chemotherapy resistance, or inducing apoptosis. Its expression level was found often significantly reduced in several cancers, including lung adenocarcinoma and squamous cell carcinoma, bladder urothelial carcinoma, or colorectal adenocarcinoma [33,39-42,46-48,50-56,69]. On the other hand, FENDRR overexpression correlated with a decreased rate of proliferation of cancer cell lines [54,70], inhibition of invasive capacity of Non-small Cell Lung Cancer (NSCLC) cells and a sharp decline in tumor growth in vitro [54]. The A549 and PC-9 lung cancer cells with induced high expression of FENDRR exhibited significantly decreased growth rate of tumor xenograft compared with their controls in vitro. $\mathrm{Xu}$ et al. [71] have reported that FENDER over-expression also suppressed migration and invasion of gastric cancer cells.

FENDRR has been proposed to play an inhibitory role in cancer by sponging miRs that target mRNAs of tumor suppressors (Table 1). FENDRR was shown to sequester miR-761 leading to an increase in metalloproteinase inhibitor TIMP2 level and thus inhibition of cell invasion $[54,55]$. In gastric cancer, FENDRR decrease increased cell migration and invasion in vitro through upregulation of metalloproteinase genes $M M P 2$ and $M M P 9$ involved in degradation of extracellular matrix [71]. FENDRR also targets oncogene promoters with, e.g., chromatin modifying PRC2 complex, leading to a decrease in the expression of those 
oncogenes. Loss of FENDRR, e.g., induced cell proliferation, epithelial-mesenchymal transition, and metastasis of NSCLC cells via EZH2 and downregulation of FOXF1 [59].

Lastly, FENDRR was linked to regulation of cancer cell drug resistance. It was found to be dramatically decreased, e.g., in the doxorubicin-resistant osteosarcoma cell lines and tissues [72]. FENDRR apparently acts as a suppressor of chemoresistance by downregulating multidrug resistance genes, coding for $\mathrm{ABC}$-transporters $\mathrm{ABCB} 1, \mathrm{ABCC} 1$ [72], and ABCC10 [70]. The overexpression of FENDRR correlated with suppression of doxorubicin resistance of osteosarcoma cells, cell cycle progression, and promoted cell apoptosis [72].

\subsection{Fibrosis}

Idiopathic Pulmonary Fibrosis (IPF) is caused by uncontrolled stimulation of fibroblasts, leading to the accumulation of ACTA2, collagen and fibronectin in the extracellular matrix, resulting in loss of tissue architecture and functioning [73,74]. The disease is incurable with a life expectancy of 3-5 years. FENDRR level was found to be decreased both in mesenchyme of fibrotic human lungs, likely due to the increased TGF- $\beta$-induced SMAD3 signaling [35,75], and in sera of lung fibrosis patients [76]. FENDRR shows anti-fibrotic effect in lung fibroblasts by (i) sponging fibroblast activating miR-214 (it contains six computationally predicted binding sites for this miR), and (ii) reducing iron level through interaction with IRP1 [35]. Iron is thought to activate pro-fibrotic TGF- $\beta$ signaling to SMAD3 which inhibits FENDRR expression and activates expression of collagen and other extracellular matrix protein genes. IRP1 binds, among others, to iron-responsive element of Transferrin Receptor TFRC mRNA (TFRC is needed for the import of iron ions in the ferric form into cells [77]), allowing for its translation. FENDRR and TFRC mRNA compete for IRP1 so that in the presence of FENDRR, more TFRC mRNA remains unbound to IRP1 and is rapidly degraded leading to the depletion of intracellular iron level.

However, the anti-fibrotic functioning of FENDRR can be tissue specific. In a mouse fibrotic heart, Fendrr level rather increased [44]. Fendrr seems to play pro-fibrotic role in the developed heart by sponging miR-106b, which targets pro-fibrotic Smad3 mRNA for degradation.

\subsection{Inflammation}

Macrophage polarization: FENDRR was identified as a positive regulator of pro-inflammatory M1 macrophage polarization via the STAT1-dependent pathway [78]. Disorders associated with macrophage polarization include fibrosis [79], cancer [80], infections [81], insulin resistance [82], atherosclerosis [83], and autoimmune disease [84]. The exact mechanism of M1 polarization is unknown. FENDRR could function in this process as a chromatin modifier, increasing the expression of pro-inflammatory CXCL10 through TrxG/MLLmediated H3K4me3 methylation, or EZH2-dependent H3K27 methylation that suppresses anti-inflammatory genes. It is also possible that $F E N D R R$ reduces iron level in macrophages, leading to activation of STAT1 signaling and M1 macrophage polarization.

Pancreatitis: In an in vitro rat model of caerulein-induced inflammation of the pancreas, pancreatitis, ANXA2 and FENDRR were found to be increased in pancreatic acinar cells [32]. FENDRR and Anxa2 upregulation correlated with an increase in pro-apoptotic BAX and a decrease in an anti-apoptotic BCL2. FENDRR was also found bound to ANXA2 and this interaction might contribute to apoptosis.

\subsection{Cardiovascular Disorders}

FENDRR was shown to be essential for heart development in mice [5,61,62]. However, FENDRR's role in cardiovascular development in humans is unknown. FENDRR was suggested to have cardio-protective role based on negative correlation of its levels in peripheral blood mononuclear cells with left ventricular mass index in hypertensive patients [85]. 


\section{Concluding Remarks}

The lncRNA FENDRR emerges as a significant cell type- and developmental stagespecific regulator of gene expression at transcriptional and post-transcriptional levels. Its own expression involves promoter activation both by a distant tissue-specific enhancer acting in cis, shared with FENDRR-neighboring FOXF1, and by trans-acting FOXF1. This kind of expression control may represent a paradigm for the regulation of other divergent gene pairs. However, the overall current understanding of FENDRR structure and functioning is just the tip of the iceberg. For instance, FENDRR spatial structure is unknown and likely depends on its multiple ligands and local environment. This picture is further complicated by the existence of numerous FENDRR isoforms, whose presence may be tissue- and developmental stage-dependent. In addition, FENDRR subcellular localization requires further clarification. In mouse embryonic lungs, it seems mostly nuclear, whereas in adult human lung fibroblasts, it localizes preferentially to the cytoplasm. Moreover, FENDRR's known ligands have been identified in in vitro experiments focused rather on testing selected proteins or miRs. However, the current knowledge already points at the importance of FENDRR in development and tissue maintenance. In vitro experiments have shown that increasing FENDRR expression can potentially be of therapeutic significance in many cancers and lung fibrosis. Nevertheless, although targeting cancer cells and fibroblasts with FENDRR can be beneficial, FENDRR overexpression in epithelia may inhibit epithelial cell proliferation and hinder restoration of organ function. Thus, therapeutic manipulation with FENDRR expression would have to be organ/tissue specific. Other challenges faced in FENDRR studies are related to its very nature as a rapidly evolving regulatory molecule or even group of molecules, taking into account all its alternatively spliced isoforms that sometimes may be involved in contradictive biological processes.

Funding: This research was supported by Grant R01HL137203 awarded by National Heart, Lung, and Blood Institute (NHLBI) to PSt.

Conflicts of Interest: The authors declare that there is no conflict of interest.

\section{References}

1. Djebali, S.; Davis, C.A.; Merkel, A.; Dobin, A.; Lassmann, T.; Mortazavi, A.; Tanzer, A.; Lagarde, J.; Lin, W.; Schlesinger, F.; et al. Landscape of transcription in human cells. Nature 2012, 489, 101-108. [CrossRef] [PubMed]

2. Mercer, T.R.; Gerhardt, D.J.; Dinger, M.E.; Crawford, J.; Trapnell, C.; Jeddeloh, J.A.; Mattick, J.S.; Rinn, J.L. Targeted RNA sequencing reveals the deep complexity of the human transcriptome. Nat. Biotechnol. 2011, 30, 99-104. [CrossRef]

3. Mattick, J.S. The state of long non-coding RNA biology. Noncoding RNA 2018, 4, 17. [CrossRef] [PubMed]

4. Rinn, J.L.; Chang, H.Y. Long noncoding RNAs: Molecular modalities to organismal functions. Annu. Rev. Biochem. 2020, 89, 283-308. [CrossRef] [PubMed]

5. Grote, P.; Wittler, L.; Hendrix, D.; Koch, F.; Währisch, S.; Beisaw, A.; Macura, K.; Bläss, G.; Kellis, M.; Werber, M.; et al. The tissuespecific lncRNA Fendrr is an essential regulator of heart and body wall development in the mouse. Dev. Cell. 2013, 24, 206-214. [CrossRef] [PubMed]

6. Khalil, A.M.; Guttman, M.; Huarte, M.; Garber, M.; Raj, A.; Rivea Morales, D.; Thomas, K.; Presser, A.; Bernstein, B.E.; van Oudenaarden, A.; et al. Many human large intergenic noncoding RNAs associate with chromatin-modifying complexes and affect gene expression. Proc. Natl. Acad. Sci. USA 2009, 106, 11667-11672. [CrossRef]

7. The RNAcentral Consortium. RNAcentral: A hub of information for non-coding RNA sequences. Nucleic Acids Res. 2019, 47, D221-D229. [CrossRef]

8. Ma, L.; Cao, J.; Liu, L.; Du, Q.; Li, Z.; Zou, D.; Bajic, V.B.; Zhang, Z. LncBook: A curated knowledgebase of human long non-coding RNAs. Nucleic Acids Res. 2019, 47, 2699. [CrossRef]

9. Harrow, J.; Frankish, A.; Gonzalez, J.M.; Tapanari, E.; Diekhans, M.; Kokocinski, F.; Aken, B.L.; Barrell, D.; Zadissa, A.; Searle, S.; et al. GENCODE: The reference human genome annotation for The ENCODE Project. Genome Res. 2012, 22, $1760-1774$. [CrossRef]

10. Deveson, I.W.; Brunck, M.E.; Blackburn, J.; Tseng, E.; Hon, T.; Clark, T.A.; Clark, M.B.; Crawford, J.; Dinger, M.E.; Nielsen, L.K.; et al. Universal alternative splicing of noncoding exons. Cell Syst. 2018, 6, 245-255.e5. [CrossRef]

11. Dreos, R.; Ambrosini, G.; Cavin Périer, R.; Bucher, P. EPD and EPDnew, high-quality promoter resources in the next-generation sequencing era. Nucleic Acids Res. 2013, 41, D157-D164. [CrossRef] [PubMed] 
12. Andersson, R.; Chen, Y.; Core, L.; Lis, J.T.; Sandelin, A.; Jensen, T.H. Human gene promoters are intrinsically bidirectional. Mol. Cell. 2015, 60, 346-347. [CrossRef] [PubMed]

13. Boque-Sastre, R.; Soler, M.; Oliveira-Mateos, C.; Portela, A.; Moutinho, C.; Sayols, S.; Villanueva, A.; Esteller, M.; Guil, S. Head-to-head antisense transcription and R-loop formation promotes transcriptional activation. Proc. Natl. Acad. Sci. USA 2015, 112, 5785-5790. [CrossRef] [PubMed]

14. Lacadie, S.A.; Ibrahim, M.M.; Gokhale, S.A.; Ohler, U. Divergent transcription and epigenetic directionality of human promoters. FEBS J. 2016, 283, 4214-4222. [CrossRef] [PubMed]

15. Jin, Y.; Eser, U.; Struhl, K.; Churchman, L.S. The ground state and evolution of promoter region directionality. Cell 2017, 170, 889-898. [CrossRef] [PubMed]

16. Chiu, A.C.; Suzuki, H.I.; Wu, X.; Mahat, D.B.; Kriz, A.J.; Sharp, P.A. Transcriptional pause sites delineate stable nucleosomeassociated premature polyadenylation suppressed by U1 snRNP. Mol. Cell 2018, 69, 648-663. [CrossRef]

17. Szafranski, P.; Dharmadhikari, A.V.; Brosens, E.; Gurha, P.; Kolodziejska, K.E.; Zhishuo, O.; Dittwald, P.; Majewski, T.; Mohan, K.N.; Chen, B.; et al. Small noncoding differentially methylated copy-number variants, including lncRNA genes, cause a lethal lung developmental disorder. Genome Res. 2013, 23, 23-33. [CrossRef] [PubMed]

18. Dello Russo, P.; Franzoni, A.; Baldan, F.; Puppin, C.; De Maglio, G.; Pittini, C.; Cattarossi, L.; Pizzolitto, S.; Damante, G. A 16q deletion involving FOXF1 enhancer is associated to pulmonary capillary hemangiomatosis. BMC Med. Genet. 2015, 16, 94. [CrossRef] [PubMed]

19. Seo, H.; Kim, J.; Park, G.H.; Kim, Y.; Cho, S.W. Long-range enhancers modulate Foxf1 transcription in blood vessels of pulmonary vascular network. Histochem. Cell Biol. 2016, 146, 289-300. [CrossRef]

20. Szafranski, P.; Herrera, C.; Proe, L.A.; Coffman, B.; Kearney, D.L.; Popek, E.; Stankiewicz, P. Narrowing the FOXF1 distant enhancer region on 16q24.1 critical for ACDMPV. Clin. Epigenetics 2016, 8, 112. [CrossRef]

21. Szafranski, P.; Liu, Q.; Karolak, J.A.; Song, X.; de Leeuw, N.; Faas, B.; Gerychova, R.; Janku, P.; Jezova, M.; Valaskova, I.; et al. Association of rare non-coding SNVs in the lung-specific FOXF1 enhancer with a mitigation of the lethal ACDMPV phenotype. Hum. Genet. 2019, 138, 1301-1311. [CrossRef]

22. Fishilevich, S.; Nudel, R.; Rappaport, N.; Hadar, R.; Plaschkes, I.; Iny Stein, T.; Rosen, N.; Kohn, A.; Twik, M.; Safran, M.; et al. GeneHancer: Genome-wide integration of enhancers and target genes in GeneCards. Database 2017, 2017, bax028. [CrossRef] [PubMed]

23. Szafranski, P.; Kośmider, E.; Liu, Q.; Karolak, J.A.; Currie, L.; Parkash, S.; Kahler, S.G.; Roeder, E.; Littlejohn, R.O.; DeNapoli, T.S.; et al. LINE- and Alu-containing genomic instability hotspot at 16q24.1 associated with recurrent and nonrecurrent CNV deletions causative for ACDMPV. Hum. Mutat. 2018, 39, 1916-1925. [CrossRef] [PubMed]

24. Szafranski, P.; Gambin, T.; Karolak, J.A.; Popek, E.; Stankiewicz, P. Unraveling regulation of the FOXF1 adjacent long non-coding RNA FENDRR in lungs. 2021. Submitted.

25. Hnisz, D.; Abraham, B.J.; Lee, T.I.; Lau, A.; Saint-André, V.; Sigova, A.A.; Hoke, H.A.; Young, R.A. Super-enhancers in the control of cell identity and disease. Cell 2013, 155, 934-947. [CrossRef]

26. Herriges, M.J.; Swarr, D.T.; Morley, M.P.; Rathi, K.S.; Peng, T.; Stewart, K.M.; Morrisey, E.E. Long noncoding RNAs are spatially correlated with transcription factors and regulate lung development. Genes Dev. 2014, 28, 1363-1379. [CrossRef] [PubMed]

27. Cabanski, C.R.; White, N.M.; Dang, H.X.; Silva-Fisher, J.M.; Rauck, C.E.; Cicka, D.; Maher, C.A. Pan-cancer transcriptome analysis reveals long noncoding RNAs with conserved function. RNA Biol. 2015, 12, 628-642. [CrossRef] [PubMed]

28. Kim, I.M.; Zhou, Y.; Ramakrishna, S.; Hughes, D.E.; Solway, J.; Costa, R.H.; Kalinichenko, V.V. Functional characterization of evolutionarily conserved DNA regions in forkhead box f1 gene locus. J. Biol. Chem. 2005, 280, 37908-37916. [CrossRef]

29. Ren, X.; Ustiyan, V.; Pradhan, A.; Cai, Y.; Havrilak, J.A.; Bolte, C.S.; Shannon, J.M.; Kalin, T.V.; Kalinichenko, V.V. FOXF1 transcription factor is required for formation of embryonic vasculature by regulating VEGF signaling in endothelial cells. Circ. Res. 2014, 115, 709-720. [CrossRef]

30. Chen, X.; Ji, Z.; Webber, A.; Sharrocks, A.D. Genome-wide binding studies reveal DNA binding specificity mechanisms and functional interplay amongst Forkhead transcription factors. Nucleic Acids Res. 2016, 44, 1566-1578. [CrossRef]

31. Yokoyama, A.; Wang, Z.; Wysocka, J.; Sanyal, M.; Aufiero, D.J.; Kitabayashi, I.; Herr, W.; Cleary, M.L. Leukemia proto-oncoprotein MLL forms a SET1-like histone methyltransferase complex with menin to regulate Hox gene expression. Mol. Cell Biol. 2004, 24, 5639-5649. [CrossRef] [PubMed]

32. Zhao, D.; Ge, H.; Ma, B.; Xue, D.; Zhang, W.; Li, Z.; Sun, H. The interaction between ANXA2 and lncRNA Fendrr promotes cell apoptosis in caerulein-induced acute pancreatitis. J. Cell. Biochem. 2018. [CrossRef] [PubMed]

33. Yang, L.; Wu, D.; Chen, J.; Chen, J.; Qiu, F.; Li, Y.; Liu, L.; Cao, Y.; Yang, B.; Zhou, Y.; et al. A functional CNVR_3425.1 damping lincRNA FENDRR increases lifetime risk of lung cancer and COPD in Chinese. Carcinogenesis 2018, 39, 347-359. [CrossRef] [PubMed]

34. Scheuermann, J.C.; Boyer, L.A. Getting to the heart of the matter: Long non-coding RNAs in cardiac development and disease. EMBO J. 2013, 32, 1805-1816. [CrossRef] [PubMed]

35. Huang, C.; Liang, Y.; Zeng, X.; Yang, X.; Xu, D.; Gou, X.; Sathiaseelan, R.; Senavirathna, L.K.; Wang, P.; Liu, L. Long Noncoding RNA FENDRR exhibits antifibrotic activity in pulmonary fibrosis. Am. J. Respir. Cell Mol. Biol. 2020, 62, 440-453. [CrossRef]

36. Karolak, J.A.; Gambin, T.; Szafranski, P.; Stankiewicz, P. Potential interactions between the TBX4-FGF10 and SHH-FOXF1 signaling during human lung development revealed using ChIP-seq. Respiratory Res. 2021, 22, 26. [CrossRef] [PubMed] 
37. Najgebauer, H.; Liloglou, T.; Jithesh, P.V.; Giger, O.T.; Varro, A.; Sanderson, C.M. Integrated omics profiling reveals novel patterns of epigenetic programming in cancer-associated myofibroblasts. Carcinogenesis 2019, 40, 500-512. [CrossRef] [PubMed]

38. Acha-Sagredo, A.; Uko, B.; Pantazi, P.; Bediaga, N.G.; Moschandrea, C.; Rainbow, L.; Marcus, M.W.; Davies, M.P.A.; Field, J.K.; Liloglou, T. Long non-coding RNA dysregulation is a frequent event in non-small cell lung carcinoma pathogenesis. Br. J. Cancer. 2020, 122, 1050-1058. [CrossRef] [PubMed]

39. Zhu, Y.; Zhang, X.; Wang, L.; Zhu, X.; Xia, Z.; Xu, L.; Xu, J. FENDRR suppresses cervical cancer proliferation and invasion by targeting miR-15a/b-5p and regulating TUBA1A expression. Cancer Cell Int. 2020, 20, 152. [CrossRef]

40. Liang, C.; Zhang, X.; Wang, H.M.; Liu, X.M.; Zhang, X.J.; Zheng, B.; Qian, G.R.; Ma, Z.L. MicroRNA-18a-5p functions as an oncogene by directly targeting IRF2 in lung cancer. Cell Death Dis. 2017, 8, e2764. [CrossRef]

41. Yin, S.L.; Xiao, F.; Liu, Y.F.; Chen, H.; Guo, G.C. Long non-coding RNA FENDRR restrains the aggressiveness of CRC via regulating miR-18a-5p/ING4 axis. J. Cell. Biochem. 2019, 121, 3973-3985. [CrossRef]

42. Zhang, G.; Han, G.; Zhang, X.; Yu, Q.; Li, Z.; Li, Z.; Li, J. Long non-coding RNA FENDRR reduces prostate cancer malignancy by competitively binding miR-18a-5p with RUNX1. Biomarkers 2018, 23, 435-445. [CrossRef]

43. Geng, H.; Guan, J. MiR-18a-5p inhibits endothelial-mesenchymal transition and cardiac fibrosis through the Notch2 pathway. Biochem. Biophys. Res. Commun. 2017, 491, 329-336. [CrossRef]

44. Gong, L.; Zhu, L.; Yang, T. Fendrr involves in the pathogenesis of cardiac fibrosis via regulating miR-106b/SMAD3 axis. Biochem. Biophys. Res. Commun. 2020, 524, 169-177. [CrossRef] [PubMed]

45. Dong, B.; Zhou, B.; Sun, Z.; Huang, S.; Han, L.; Nie, H.; Chen, G.; Liu, S.; Zhang, Y.; Bao, N.; et al. LncRNA-FENDRR mediates VEGFA to promote the apoptosis of brain microvascular endothelial cells via regulating miR-126 in mice with hypertensive intracerebral hemorrhage. Microcirculation 2018, 25, e12499. [CrossRef] [PubMed]

46. Zhu, X.; Li, H.; Long, L.; Hui, L.; Chen, H.; Wang, X.; Shen, H.; Xu, W. miR-126 enhances the sensitivity of non-small cell lung cancer cells to anticancer agents by targeting vascular endothelial growth factor A. Acta Biochim. Biophys. Sin. (Shanghai) 2012, 44, 519-526. [CrossRef] [PubMed]

47. Gong, C.; Fang, J.; Li, G.; Liu, H.H.; Liu, Z.S. Effects of microRNA-126 on cell proliferation, apoptosis and tumor angiogenesis via the down-regulating ERK signaling pathway by targeting EGFL7 in hepatocellular carcinoma. Oncotarget 2017, 8, 52527-52542 [CrossRef] [PubMed]

48. Otsubo, T.; Akiyama, Y.; Hashimoto, Y.; Shimada, S.; Goto, K.; Yuasa, Y. MicroRNA-126 inhibits SOX2 expression and contributes to gastric carcinogenesis. PLoS ONE 2011, 6, e16617. [CrossRef]

49. Zhang, F.; Ni, H.; Li, X.; Liu, H.; Xi, T.; Zheng, L. LncRNA FENDRR attenuates adriamycin resistance via suppressing MDR1 expression through sponging HuR and miR-184 in chronic myelogenous leukaemia cells. FEBS Lett. 2019, 593, $1993-2007$. [CrossRef]

50. He, Z.; Wang, X.; Huang, C.; Gao, Y.; Yang, C.; Zeng, P.; Chen, Z. The FENDRR/miR-214-3P/TET2 axis affects cell malignant activity via RASSF1A methylation in gastric cancer. Am. J. Transl. Res. 2018, 10, 3211-3223.

51. Yang, T.S.; Yang, X.H.; Wang, X.D.; Wang, Y.L.; Zhou, B.; Song, Z.S. MiR-214 regulate gastric cancer cell proliferation, migration and invasion by targeting PTEN. Cancer Cell Int. 2013, 13, 68. [CrossRef] [PubMed]

52. Qian, G.; Jin, X.; Zhang, L. LncRNA FENDRR upregulation promotes hepatic carcinoma cells apoptosis by targeting miR-362-5p via NPR3 and p38-MAPK pathway. Cancer Biother. Radiopharm. 2020, 35, 629-639. [CrossRef] [PubMed]

53. Yu, Z.; Zhao, H.; Feng, X.; Li, H.; Qiu, C.; Yi, X.; Tang, H.; Zhang, J. Long non-coding RNA FENDRR acts as a miR-423-5p sponge to suppress the Treg-mediated immune escape of hepatocellular carcinoma cells. Mol. Ther. Nucleic Acids 2019, 17, 516-529. [CrossRef]

54. Zhang, M.-Y.; Zhang, Z.-L.; Cui, H.-X.; Wang, R.-K.; Fu, L. Long non-coding RNA FENDRR inhibits NSCLC cell growth and aggressiveness by sponging miR-761. Eur. Rev. Med. Pharmacol. Sci. 2018, 22, 8324-8332. [PubMed]

55. Zhang, G.; Wang, Q.; Zhang, X.; Ding, Z.; Liu, R. LncRNA FENDRR suppresses the progression of NSCLC via regulating miR-761/TIMP2 axis. Biomed. Pharmacother. 2019, 118, 109309. [CrossRef] [PubMed]

56. Liu, Y.; Xie, D.; He, Z.; Zheng, L. Integrated analysis reveals five potential ceRNA biomarkers in human lung adenocarcinoma. Peer J. 2019, 7, e6694. [CrossRef] [PubMed]

57. Thorne, J.L.; Battaglia, S.; Baxter, D.E.; Hayes, J.L.; Hutchinson, S.A.; Jana, S.; Millican-Slater., R.A.; Smith, L.; Teske, M.C.; Wastall, L.M.; et al. MiR-19b non-canonical binding is directed by HuR and confers chemosensitivity through regulation of P-glycoprotein in breast cancer. Biochim. Biophys. Acta Gene Regul. Mech. 2018, 1861, 996-1006. [CrossRef] [PubMed]

58. He, W.; Zhong, G.; Wang, P.; Jiang, C.; Jiang, N.; Huang, J. Downregulation of long noncoding RNA FENDRR predicts poor prognosis in renal cell carcinoma. Oncol. Lett. 2019, 17, 103-112. [CrossRef] [PubMed]

59. Miao, L.; Huang, Z.; Zengli, Z.; Li, H.; Chen, Q.; Yao, C.; Cai, H.; Xiao, Y.; Xia, H.; Wang, Y. Loss of long noncoding RNA FOXF1-AS1 regulates epithelial-mesenchymal transition, stemness and metastasis of non-small cell lung cancer cells. Oncotarget 2016, 7, 68339-68349. [CrossRef]

60. Maksour, S.; Ooi, L.; Dottori, M. More than a Corepressor: The role of CoREST proteins in neurodevelopment. Eneuro 2020, 7, ENEURO.0337-19.2020. [CrossRef]

61. Sauvageau, M.; Goff, L.A.; Lodato, S.; Bonev, B.; Groff, A.F.; Gerhardinger, C.; Sanchez-Gomez, D.B.; Hacisuleyman, E.; Li, E.; Spence, M.; et al. Multiple knockout mouse models reveal lincRNAs are required for life and brain development. Elife 2013, 2, e01749. [CrossRef] [PubMed] 
62. Lai, K.M.; Gong, G.; Atanasio, A.; Rojas, J.; Quispe, J.; Posca, J.; White, D.; Huang, M.; Fedorova, D.; Grant, C.; et al. Diverse phenotypes and specific transcription patterns in twenty mouse lines with ablated lincRNAs. PLoS ONE 2015, 10, e0125522. [CrossRef] [PubMed]

63. GTEx Consortium. The Genotype-Tissue Expression (GTEx) project. Nat. Genet. 2013, 45, 580-585. [CrossRef] [PubMed]

64. Fagerberg, L.; Hallström, B.M.; Oksvold, P.; Kampf, C.; Djureinovic, D.; Odeberg, J.; Habuka, M.; Tahmasebpoor, S.; Danielsson, A.; Edlund, K.; et al. Analysis of the human tissue-specific expression by genome-wide integration of transcriptomics and antibody-based proteomics. Mol. Cell. Proteom. 2014, 13, 397-406. [CrossRef]

65. Karolak, J.A.; Gambin, T.; Szafranski, P.; Maywald, R.L.; Heaney, J.D.; Stankiewicz, P. Transcriptomic analysis of ACDMPV. 2021. In Preparation.

66. Chi, Y.; Wang, D.; Wang, J.; Yu, W.; Yang, J. Long non-coding RNA in the pathogenesis of cancers. Cell 2019, 8, 1015. [CrossRef] [PubMed]

67. Kong, Y.; Lu, Z.; Liu, P.; Liu, Y.; Wang, F.; Liang, E.Y.; Hou, F.F.; Liang, M. Long noncoding RNA: Genomics and relevance to physiology. Compr. Physiol. 2019, 9, 933-946.

68. Aprile, M.; Katopodi, V.; Leucci, E.; Costa, V. LncRNAs in Cancer: From garbage to junk. Cancers 2020, 12, 3220. [CrossRef] [PubMed]

69. Herrera-Merchan, A.; Cuadros, M.; Rodriguez, M.I.; Rodriguez, S.; Torres, R.; Estecio, M.; Coira, I.F.; Loidi, C.; Saiz, M.; Carmona-Saez, P.; et al. The value of lncRNA FENDRR and FOXF1 as a prognostic factor for survival of lung adenocarcinoma. Oncotarget 2017, 11, 1172-1185. [CrossRef]

70. $\mathrm{Xu}, \mathrm{R}$.; Han, Y. Long non-coding RNA FOXF1 adjacent non-coding developmental regulatory RNA inhibits growth and chemotherapy resistance in non-small cell lung cancer. Arch. Med. Sci. 2019, 15, 1539-1546. [CrossRef]

71. Xu, T.P.; Huang, M.D.; Xia, R.; Liu, X.X.; Sun, M.; Yin, L.; Chen, W.M.; Han, L.; Zhang, E.B.; Kong, R.; et al. Decreased expression of the long non-coding RNA FENDRR is associated with poor prognosis in gastric cancer and FENDRR regulates gastric cancer cell metastasis by affecting fibronectin1 expression. J. Hematol. Oncol. 2014, 7, 63. [CrossRef] [PubMed]

72. Kun-Peng, Z.; Xiao-Long, M.; Chun-Lin, Z. LncRNA FENDRR sensitizes doxorubicin-resistance of osteosarcoma cells through down-regulating ABCB1 and ABCC1. Oncotarget 2017, 8, 71881-71893. [CrossRef] [PubMed]

73. Kolahian, S.; Fernandez, I.E.; Eickelberg, O.; Hartl, D. Immune mechanisms in pulmonary fibrosis. Am. J. Respir. Cell Mol. Biol. 2016, 55, 309-322. [CrossRef] [PubMed]

74. Khalil, N.; Greenberg, A.H. The role of TGF-beta in pulmonary fibrosis. Ciba Found Symp. 1991, 157, $194-207$.

75. Senavirathna, L.K.; Huang, C.; Pushparaj, S.; Xu, D.; Liu, L. Hypoxia and transforming growth factor $\beta 1$ regulation of long non-coding RNA transcriptomes in human pulmonary fibroblasts. Physiol. Rep. 2020, 8, e14343. [CrossRef]

76. Di Mauro, S.; Scamporrino, A.; Fruciano, M.; Filippello, A.; Fagone, E.; Gili, E.; Scionti, F.; Purrazzo, G.; Di Pino, A.; Scicali, R.; et al. Circulating coding and long non-coding RNAs as potential biomarkers of Idiopathic Pulmonary Fibrosis. Int. J. Mol. Sci. 2020, 21, 8812. [CrossRef]

77. Bogdan, A.R.; Miyazawa, M.; Hashimoto, K.; Tsuji, Y. Regulators of iron homeostasis: New players in metabolism, cell death, and disease. Trends Biochem. Sci. 2016, 41, 274-286. [CrossRef]

78. Munteanu, M.C.; Huang, C.; Liang, Y.; Sathiaseelan, R.; Zeng, X.; Liu, L. Long non-coding RNA FENDRR regulates IFN $\gamma$-induced M1 phenotype in macrophages. Sci. Rep. 2020, 10, 13672. [CrossRef]

79. Braga, T.T.; Agudelo, J.S.; Camara, N.O. Macrophages during the fbrotic process: M2 as friend and foe. Front. Immunol. 2015, 6, 602. [CrossRef]

80. Rufell, B.; Coussens, L.M. Macrophages and therapeutic resistance in cancer. Cancer Cell 2015, 27, 462-472. [CrossRef]

81. Labonte, A.C.; Tosello-Trampont, A.C.; Hahn, Y.S. The role of macrophage polarization in infectious and inflammatory diseases Mol. Cells 2014, 37, 275-285. [CrossRef] [PubMed]

82. Olefsky, J.M.; Glass, C.K. Macrophages, inflammation, and insulin resistance. Annu. Rev. Physiol. 2010, 72, 219-246. [CrossRef] [PubMed]

83. Leitinger, N.; Schulman, I.G. Phenotypic polarization of macrophages in atherosclerosis. Arterioscler. Tromb. Vasc. Biol. 2013, 33, 1120-1126. [CrossRef] [PubMed]

84. Liu, C.; Li, Y.; Yu, J.; Feng, L.; Hou, S.; Liu, Y.; Guo, M.; Xie, Y.; Meng, J.; Zhang, H.; et al. Targeting the shift from M1 to M2 macrophages in experimental autoimmune encephalomyelitis mice treated with Fasudil. PLoS ONE 2013, 8, e54841. [CrossRef] [PubMed]

85. Kontaraki, J.E.; Marketou, M.E.; Kochiadakis, G.E.; Maragkoudakis, S.; Konstantinou, J.; Vardas, P.E.; Parthenakis, F.I. The long non-coding RNAs MHRT, FENDRR and CARMEN, their expression levels in peripheral blood mononuclear cells in patients with essential hypertension and their relation to heart hypertrophy. Clin. Exp. Pharmacol. Physiol. 2018, 45, 1213-1217. [CrossRef] [PubMed] 